\title{
The Effect of Country of Origin, Perceived Quality, And Brand Image on the Purchase Intention of Etude House Cosmetics
}

\author{
Cindy Lestari Lie \\ Universitas Pelita Harapan, Indonesia \\ E-mail: cindslie@gmail.com \\ Innocentius Bernarto \\ Universitas Pelita Harapan, Indonesia \\ E-mail: bernarto227@gmail.com
}

Received: August 23, 2019 Accepted: November 13, 2019 Published: December 14, 2019

doi:10.5296/bmh.v7i2.15324

URL: http://dx.doi.org/10.5296/bmh.v7i2.15324

\begin{abstract}
The many interests of Indonesians for imported cosmetics have invited many foreign companies to enter the Indonesian market, including one of the leading cosmetic brands from South Korea, Etude House. The purpose of this research is to analyse and test the positive effects of country of origin, perceived quality, and brand image on the purchase intention of Etude House cosmetics. Based on the purpose of the research, the proposed hypotheses are: (1) The country of origin of a product affects positively on the purchase intention of a consumer, (2) The perceived quality of a product affects positively on the purchase intention of a consumer, and (3) The brand image of a product affects positively on the purchase intention of a consumer. The sample consists of Etude House consumers in Indonesia who are students of the University of Pelita Harapan, with a total of 146 respondents. The sampling technique used in the research is Convenience sampling method. The statistical analysis is applied by the approach of Partial Least Square - Structural Equation Modeling (PLS-SEM) method, with the program SmartPLS. The end result of this research has shown that (1) The country of origin of a product does not affect positively on purchase intention, (2) The perceived quality of a product has a positive and the most significant effect on purchase intention, and (3) The brand image of a product also has a positive and significant effect on purchase intention.
\end{abstract}

Keywords: country of origin, brand image, perceived quality, purchase intention. 


\section{Introduction}

\subsection{Background}

In the present period of globalization, improvements in the field of science and innovation have made it possible for individuals to be aware of new global merchandises (Gillespie, McBride, $\&$ Riddle, 2010). Thus, The Indonesian economy has been depending on item imports as one of the principle commitments to the improvement of its economy. Imported beauty sales in 2015 has reached up to US\$441 million (Adhitya, 2018). Based on the data of beauty product sales in 2016, 48\% of consumers preferred global brand cosmetics as their brands of choice ("Consumer goods to Indonesia - Austrade", 2018). The Brand Etude House has opened about 32 stores throughout Indonesia (Wulandari, 2013). In order to maintain and gain better purchase intention from current and new consumers of the brand, the company should always consider the effects of Country of Origin, Perceived Quality and Brand Image on the Purchase Intention of the brand.

\subsection{Research Questions}

There are 3 objectives in this research to be analyzed. First, does country of origin have a positive influence on the purchase intention of Etude House Cosmetics? Second, does perceived quality have a positive influence on the purchase intention of Etude House Cosmetics? Lastly, does brand image have a positive influence on the purchase intention of Etude House Cosmetics?

\subsection{Literatur Review}

\subsubsection{Purchase Intention}

Intention of purchase is a situation when the customer has not made a transaction but has entered the stage of the decision making process (Keller, 2012). This attitude will last until consumers get satisfaction from the products purchased, so consumers will remain loyal in using these products and even consumers will recommend these products to other people to take the product. Purchase intention cannot be separated from the consumer's purchase decision theory, because intention is one of the final processes of purchasing decisions from consumers. Intention is a plan or how someone will behave from a particular situation in certain ways whether or not someone will (Schiffman \& Kanuk, 2009). Purchase intention is obtained from a learning process and thinking process that form a perception (Mowen, 2006).

Purchase intention is part of the behavior component in consuming attitude. Meanwhile, Stigler (Schiffman \& Kanuk, 2009, p. 240) states that a brand known by the buyer will generate interest in making purchasing decisions. The symbol and visualization of a product have a meaning that they can affect customer purchase intentions. Based on the description above, it can be concluded that purchase intention is a concentration of individual attention to an item that is accompanied by a feeling of pleasure towards the item, so interest causes desire and then, a feeling arises and convinces the individual that the item has benefits. Then, the individual wants to own the item by buying it. The intention of the purchase is also the inclination of customer to buy a certain brand of product by considering the level of possibility. 


\subsection{Hypothesis Development}

\subsubsection{The Relationship Between Country of Origin and Purchase Intention}

Country of Origin is a person's association and mental trust in a product that is triggered by country of origin of the product (Kotler \& Keller, 2012). Even when the quality of the products is sometimes not as good as the quality of the local products (for certain products). Based on the facts occurring at this time, the Country of Origin (COO) has become one of the considerations and raised topics in international marketing researches. Country of Origin is the country of origin of a brand that influences the purchase intentions of a consumer, which is one of the most important elements that is essential to the consumer buying behaviour. Country of Origin affects the perception and image of the products meaning that consumers tend to have specific and certain impressions of products based on the country that they were produced from. Their impressions maybe stereotypical as the quality of the product is strongly associated with the origin country (Shamindra \& Saroj, 2011). Country of Origin is used as a quality standard for a product even before the product is actually bought.

Based on previous investigations, researchers have found that country-of-origin plays a significant role and has direct effect in the perception of consumers towards brands and products of specific countries (Degoma \& Shetemam, 2014; Hanzaee \& Khosrozadeh, 2011). Other studies have also shown that consumers takes consideration of where a product was made from, and directly affects the purchasing decision of perceived quality of domestic and foreign products, by the country's economic, political and technological advancements (Parkvithee \& Miranda 2012; Rezvani, Dehkordi, Rahman, Fouladivandal, Eghtebasi \& Habibi, 2012; Wang, Barnes \& Ahn, 2012). Therefore, the hypothesis formulated is as follows:

\section{$H_{1}$ : The Country-of-origin affects positively on the Purchase Intention of Etude Cosmetics.}

\subsubsection{The Relationship Between Perceived Quality and Purchase Intention}

Perceived Quality is the consumer's verdict regarding to the superiority of a product's quality based on subjective perceptions (Erdogmus \& Turan, 2012), originating from the satisfaction of customer needs which leads to the consumers' perceptions of quality which is the behavior that arises from within the superiority of a product or service (Kotler, Armstrong, Saunders, \& Wong, 2008). Perceived quality is how customers judge the superiority, experience and attitude of customers towards a particular product brand compared to competitors (Beneke, Flynn, Greig, \& Mukaiwa, 2013). Thus, we can draw the conclusion that perceived quality is defined as how far a product meets the desires of the customer. This perception is relative because it corresponds to the views and thoughts of each consumer.

Based on previous investigations, researchers have concluded that perceived quality is one of the most important aspects of a product that affects a consumer's purchase intention positively and significantly (Nor, Yunus, \& Edura, 2016). Perceived quality is much more important and considered by the consumers' intentions of purchasing and re-purchasing a product, as the higher the perceived quality of a product, the higher the perceived value is considered by the consumers (Degoma \& Shetemam, 2014, Yee \& San, 2011). Moreover, perceived quality is more impactful to the purchase intention of a product compared to the perceived price of the 
product (Jaafar \& Laip, 2012; Wu, Yeh, \& Hsiao, 2011). According to the associated literature, the hypothesis to be verified and used in the study is as follows:

\section{$\mathrm{H}_{2}$ : The Perceived Quality affects positively on the Purchase Intention of Etude Cosmetics.}

\subsubsection{The Relationship Between Brand Image and Purchase Intention}

The American Marketing Association (AMA) defines brand as "a name, term, sign, symbols, or designs, or combinations of them, intended to identify the goods or services of one seller or group of sellers and to differentiate them from those of competitors" (Kotler \& Keller 2012, p. 263). Brand Image is a perception of a brand that is a reflection of memory consumers will associate with the brand (Kotler \& Keller, 2009). It can also be explained that brand image is a subjective and emotional picture of the customer, and is a particular form or picture of a trace meaning left behind in the minds of consumers (Wijaya, 2013). It also guides the consumers' behavior towards the brand, whether to try it or leave it, because of a bad or irrelevant image with the needs of consumers. Brand image is what customers think or feel when they hear or see the name of a brand and is also called brand memory that contains the target market interpretation of product attributes or characteristics, product benefits, usage situation and marketer characteristics (Rosyidi, 2009).

Brand image was also proven to have a positively significant and direct effect on a consumer's purchase intention. Brand Image influences a consumer's purchase intention, as it reflects the consumers' personal judgements and evaluations regarding the act of buying products publicly (Chih, Lin \& Chen, 2013). Consumer purchase intention and loyalty are heavily influenced by the quality of a cosmetic products (Batra \& Homer, 2004). High quality products help to create and maintain the confidence of consumers' purchase decision. Consumers are always concerned with the quality of the cosmetics (Priyanga \& Krishnaveni, 2016), thus, a consistent brand image and positioning help to increase the brand's future success (Shah, Aziz, Jaffari, Ejaz, Fatima, \& Sherazi, 2012; Tulipa \& Muljani, 2015). Therefore, the hypothesis proposed is as follows:

\section{$\mathrm{H}_{3}$ : The Brand Image affects positively on the Purchase Intention of Etude Cosmetics.}

\subsubsection{Research Model}

Based on the theoretical framework above, the exogenous constructs are Country of Origin (COO), Perceived Quality (PQ), Brand Image (BI), and the endogenous construct is Purchase Intention (PI). The conceptual framework can be concluded as:

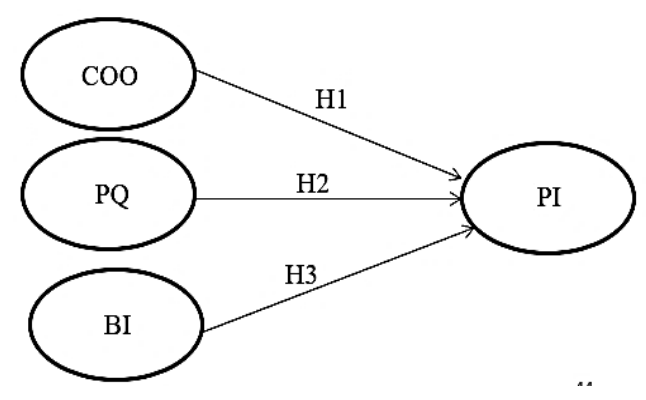

Figure 1. The research model. 


\section{Research Method}

This research is a survey research, namely by method of collecting data and information by handing out online questionnaires via Google docs to the respondents. The population that will be used in this study is students of the UPH, Karawaci, Tangerang, Indonesia. The sampling technique used is convenience sampling method, which is a collection of information from the population that is easily obtained and able to provide information. The number of samples taken is 146 respondents who are students of UPH, and have purchased Etude House products, with the minimum age of 18 . This research uses the partial least square-structural equation modeling (PLS-SEM) approach analyzed by SmartPLS 3.2.7 program. PLS-SEM is a variant-based structural equation analysis that can simultaneously perform measurement models at the same level as testing of structural models. The measurement model is used to test validity and reliability, while the structural model used is causal test (Abdillah \& Hartono, 2015). The hypothesis testing will use the $t_{\text {value }}$ of the data where the value should not be lower than the $t_{\text {table }}$ value of 1.65 (level of significance $=5 \%$ ). The indicators of the constructs are adapted from multiple previous researches, and are measured by the 5-points Likert scale, namely $1=$ Strongly Disagree, $2=$ Disagree, $3=$ Neutral, $4=$ Agree, and $5=$ Strongly Agree .

Country of origin is understood as the effect that appears in the consumers' perceptions affected by the location of where a product is produced (Czinkota \& Ronkainen, 2010). There are 7 items used, which are the country innovation in production, level of technological progress, the production design, creativity, quality of production, the prestige of the brand's home country, and the image of the country as a developed country that are adapted from Ko, Kyung, and Hao (2015) and Yasin, Noor, and Mohamad (2007). Perceived Quality can be defined as the consumers' perception towards the overall quality or the relative superiority of a product or service to relevant alternatives in accordance with the consumer's objectives (Kotler $\&$ Keller, 2012). There are 6 items used in this construct, Performance, Resilience, Reliability, Aesthetics, Conformity, and Results which are adapted from Garvin (in Ko et al., 2015).

Brand image is a consumer-based brand knowledge, that can be considered as the type of association that comes to mind when consumers are remembering a particular brand (Keller, 2012). There are 8 items used, Benefits, Culture, Value, Corporate image that are adapted from Kotler and Keller (2012), and Brand Personality, Association, Knowledge, and Competence that are adapted from Hartono (2013). Purchase intention is something that represents consumers who have the possibility, will or plan to buy a product or service in the future. This increased interest in purchasing means an increase in the likelihood of purchase (Schiffman \& Kanuk, 2009). There are 5 items used, Transactional interest, Referential interest, Preferential interest, and Explorative interest that are adapted from Bhakar, Bhakar, and Bhakar (2013).

\section{Results}

\subsection{Respondent Profile}

The majority of the respondents are females of ages 18-21 years old, with the average expenditure of IDR $100,000-300,000$. Table 1 shows the detailed characteristics of the respondents: 


\section{1) Macrothink}

Table 1. Respondent profile

\begin{tabular}{lll}
\hline & No. of Respondents $(\mathrm{N}=146)$ & Percentage \\
\hline Gender & & \\
\hline Male & 2 & $1 \%$ \\
Female & 144 & $99 \%$ \\
\hline Age & & \\
\hline $18-21$ years old & 116 & $80 \%$ \\
22-25 years old & 30 & $20 \%$ \\
\hline Average Cosmetics Expenditure & & \\
\hline$<$ IDR 100,000 & 23 & $16 \%$ \\
IDR 100,000 - IDR 300,000 & 73 & $50 \%$ \\
IDR 300,000 - IDR 500,000 & 36 & $25 \%$ \\
$>$ IDR 500,000 & 14 & $9 \%$ \\
\hline
\end{tabular}

Source: Data analysis result.

\subsection{Measurement Model}

The validity and reliability testing is carried out before evaluating the structural model. The validity is tested by calculating the average variance extracted (AVE), loading factors and discriminant validity (Hair, Hult, Ringle and Sarstedt (2014). The rule of thumb is used for convergent validity, namely the loading factor should be $>0.7$ (but 0.5-0.6 is still acceptable) and AVE $>0.50$ (Abdillah \& Hartono, 2015). In testing the discriminant validity, it can be proven by the value of loading factor which is greater than the correlation between other latent constructs that are greater than 0.5, based on the rule of thumb (Abdillah \& Hartono, 2015). The reliability testing is carried out by composite reliability (CR) where the values should be $>0.7$, but 0.6 is still acceptable.

The Convergent Validity test was taken for each indicators, but a few indicators were proven to be invalid and had to be removed, as the loading factors were below the rule of thumb which should be $>0.5$ (Abdillah \& Hartono, 2015). The first variable COO (Country of Origin) initially had 7 indicators, but 2 indicators were invalid, COO1 (0.288), COO2 (0.380), The second variable PQ (Perceived Quality) initially had 6 indicators, but one indicator was invalid, PQ5 (0.419), BI (Brand Image) initially had 8 indicators but 3 indicators were invalid, BI1(0.468), BI4(0.499) BI8(0.494). A Discriminant Validity test was also taken to further examination of the validity of the data, but indicators $\mathrm{COO} 7(0.500) \mathrm{BI} 2(0.523)$, BI5 (0.686) had to be removed, in order to increase the strength of correlation between each variables. Table 1.2 shows the validity and reliability tests and Table 1.3 shows the discriminant validity of the data, which is as follows: 
Table 2. Validity and Reliability test

\begin{tabular}{|c|c|c|c|}
\hline Indicator & Description & Loading Factor & Result \\
\hline \multicolumn{4}{|c|}{ Country of origin $(\mathrm{AVE}=\mathbf{0 . 5 6 0}, \mathrm{CR}=\mathbf{0 . 8 3 2})$} \\
\hline $\mathrm{COO3}$ & $\begin{array}{l}\text { South Korea, the country of the brand Etude House is a } \\
\text { technologically advanced country in producing cosmetic } \\
\text { products }\end{array}$ & 0.839 & Valid \\
\hline COO4 & $\begin{array}{l}\text { South Korea, the country of the brand Etude House has a good } \\
\text { reputation in producing cosmetic products. }\end{array}$ & 0.795 & Valid \\
\hline COO5 & $\begin{array}{l}\text { South Korea, the country of the brand Etude House, is known } \\
\text { for their innovations in producing cosmetic products. }\end{array}$ & 0.788 & Valid \\
\hline COO6 & $\begin{array}{l}\text { South Korea, the country of the brand Etude House, is known } \\
\text { for their beautiful idols and celebrities. }\end{array}$ & 0.530 & Valid \\
\hline \multicolumn{4}{|c|}{ Perceived Quality $(\mathrm{AVE}=0.626, \mathrm{CR}=0.865)$} \\
\hline PQ1 & $\begin{array}{l}\text { I feel satisfied when I use cosmetic products from the brand } \\
\text { Etude House }\end{array}$ & 0.896 & Valid \\
\hline PQ2 & Etude House cosmetic products are long lasting (durable) & 0.721 & Valid \\
\hline PQ3 & Etude House cosmetics contain safe ingredients. & 0.731 & Valid \\
\hline PQ4 & $\begin{array}{l}\text { The variety of cosmetics produced by Etude House caters to } \\
\text { my aesthetic needs. }\end{array}$ & 0.804 & Valid \\
\hline PQ6 & The brand Etude House makes me look classy. & 0.792 & Valid \\
\hline \multicolumn{4}{|c|}{ Brand Image $(\mathrm{AVE}=0.531, \mathrm{CR}=0.694)$} \\
\hline BI3 & The brand Etude House has a good brand image. & 0.693 & Valid \\
\hline BI6 & The brand Etude House produces high quality products. & 0.841 & Valid \\
\hline BI7 & $\begin{array}{l}\text { By using cosmetic products from Etude House, I feel as } \\
\text { beautiful as Korean idols. }\end{array}$ & 0.780 & Valid \\
\hline \multicolumn{4}{|c|}{ Purchase Intention $(\mathrm{AVE}=0.732, \mathrm{CR}=0.893)$} \\
\hline PI1 & $\begin{array}{l}\text { I am interested in using the products from the brand Etude } \\
\text { House. }\end{array}$ & 0.856 & Valid \\
\hline PI2 & $\begin{array}{l}\text { I am interested in buying the products from the brand Etude } \\
\text { House. }\end{array}$ & 0.869 & Valid \\
\hline P13 & I am willing to recommend the brand Etude House to others. & 0.823 & Valid \\
\hline PI4 & $\begin{array}{l}\text { I am interested in repurchasing cosmetic products from the } \\
\text { brand Etude House. }\end{array}$ & 0.894 & Valid \\
\hline PI5 & $\begin{array}{l}\text { I am interested in finding more information about the brand } \\
\text { Etude House and their products. }\end{array}$ & 0.834 & Valid \\
\hline
\end{tabular}

Source: Data analysis results.

Table 2. shows that all of the values of the data are considered to be valid and reliable as the AVE value $>0.5$, the Composite Reliability is $>0.6$ and the loading factors are considered valid, as they are $>0.7$. 
Table 3. Discriminant Validity

\begin{tabular}{lllll}
\hline & BI & COO & PI & PQ \\
\hline BI & $\mathbf{0 . 7 7 4}$ & & & \\
COO & 0.513 & $\mathbf{0 . 7 4 8}$ & & \\
PI & 0.757 & 0.402 & $\mathbf{0 . 8 5 6}$ & \\
PQ & 0.773 & 0.491 & 0.827 & $\mathbf{0 . 7 9 1}$ \\
\hline
\end{tabular}

Source: Data analysis results.

The next validity test is to test the discriminant validity, by the use of the Fornell-Larcker criteria. According to Hair et al. (2014), Fornell-Larcker, the criteria is "the square root of the AVE of each construct should be higher than the construct's highest correlation with any other construct in the model" (p.111). Table 3 reveals that all constructs meet the Fornell-Larcker criteria.

\subsection{Structural Model}

Structural model shows the relationships or strength of estimation between constructs. Multicollinearity tests were carried out to test the correlation between exogenous constructs and tested by the Variance Infraction Factor (VIF) value. The R-Square value is tested on the endogenous construct which is the predictive power of the structural model which can be used to explain the strength of the endogenous constructs (Hair et al., 2014).

\subsubsection{Multicollinearity and $\mathrm{R}^{2}$}

Multicollinearity test is a test that identifies correlation between exogenous constructs. In this test, Variance Inflation Factor (VIF) is used, and the value should be less than 5 (Hair et al., 2014). In Table 4, the results of the multicollinearity test can be seen more clearly:

Table 4. Multicollinearity test

\begin{tabular}{lll}
\hline Construct & VIF & Result \\
\hline COO & 1.399 & Valid \\
PQ & 2.564 & Valid \\
BI & 2.639 & Valid \\
\hline
\end{tabular}

Source: Data analysis results.

Table 4 shows that all exogenous constructs, including COO (1.399), PQ (2.564), and BI (2.639) have passed the multicollinearity test, as the results of the VIF values are less than 10. The Inner Model in PLS-SEM also requires the value of R-Square test (the coefficient of determination) of the endogenous construct. R-Square values of $0.75,0.50$ and 0.25 show that the values of R-Square is substantial, moderate or weak (Hair et al., 2014). Table 5 shows the R-Square of Purchase Intention: 
Table 5. R-Square Value

Source: Data analysis results.

\begin{tabular}{ll}
\hline Construct & R-Square \\
$P I$ & 0.721 \\
\hline
\end{tabular}

Based on Table 5, it can be seen that the value of R-Square on the Purchase Intention construct is $0.721(72.1 \%)$. Thus, the value of R-Square shows that the Purchase Intention construct has a strong model influenced by exogenous construct Country of Origin, Perceived Quality and Brand Image, and is affected by other constructs for the remaining $27.9 \%$.

\subsubsection{Hypothesis Testing}

The hypothesis testing has a criterion to measure the significance of the data, by observing the

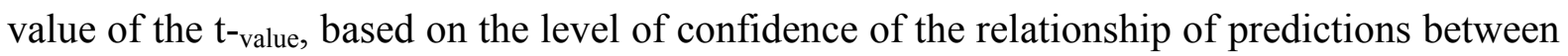
constructs supported by the conceptual foundation and previous empirical studies (Abdillah \& Hartono, 2015). The hypothesis testing criteria is supported when the $t$-value is above the $t$-statitics which is 1.65 . (level of significance $=5 \%$, one tailed-test). The following is the detailed description of Table 6 :

Table 6. Hypothesis testing

\begin{tabular}{llll}
\hline Hypothesis & $\begin{array}{l}\text { Standardized } \\
\text { Coefficient }\end{array}$ & t-value & Decision \\
\hline $\begin{array}{l}\mathrm{H}_{1} \text { : The Country-of-origin (COO) affects positively on } \\
\text { the Purchase Intention (PI) of Etude Cosmetics. }\end{array}$ & -0.061 & 1.131 & Not Supported \\
$\begin{array}{l}\mathrm{H}_{2}: \text { The Perceived Quality (PQ) affects positively on the } \\
\begin{array}{l}\text { Purchase Intention (PI) of Etude Cosmetics. } \\
\mathrm{H}_{3} \text { : The Brand Image (BI) affects positively on the }\end{array}\end{array}$ & 0.614 & 7.799 & Supported \\
Purchase Intention (PI) of Etude Cosmetics. & 3.364 & Supported \\
\hline
\end{tabular}

Source: Data analysis results.

Based on Table 6, it can be seen that two of the hypotheses were supported and positively significant, and one hypothesis was not supported. The supported hypothesis results were $\mathrm{H}_{2}$ and $\mathrm{H}_{3}$, while Hypothesis $\mathrm{H} 1$ was not supported, as the $\mathrm{t}$-value was below 1.65 (level of significance $=5 \%$, one tailed-test).

\section{Conclusion}

The following conclusions were drawn from the data analysis in this research. From the results of data that have been collected from Etude House consumers as many as 146 respondents, the multicollinearity test results show the value below 5 , so it can be concluded that there were no symptoms of multicollinearity. Then, for the results of testing the value of R-Square, it can be concluded that the endogenous construct (Purchase Intention) has a model strongly influenced by exogenous constructs (Country of Origin, Perceived Quality, Brand Image) by $72.1 \%$ and 
$27.9 \%$ from other constructs. Based on the results of the first hypothesis test, it can be seen by the results of the hypothesis testing, that the results of data were not significant and the results of Hypothesis 1 of this study were consistent with the results of the hypothesis conducted by Ko et al. (2015) where the results of the first hypothesis were not supported. As the indicators of Country of Origin increases, the Purchase Intention decreases.

This is because Etude House cosmetics consumers do not consider where the country of origin of the product originated in the interest of purchasing and re-purchasing the cosmetic products from Etude House. However, there are other factors that influence consumers in the purchase intention in the products. These factors include the quality of cosmetic products of the brand Etude House, that is satisfactory to the consumers when they use the products, the affordability of Etude House cosmetic products that is relatively affordable to the market, and the ability for the brand Etude House to have a trendy and aesthetically pleasing packaging that attracts the purchase intention of the consumers. This could also be caused by the effect of the globalization of MNC companies, producing their products in other countries, for the benefit of economies of scale and efficient cost of production. Such as the Spanish fashion label Zara, it has taken the global strategy of manufacturing. Zara focuses on outsourcing their production in developing countries such as China, Cambodia, Bangladesh and Indonesia, and for more efficient labor and production costs, the design and value added stages of the production such as designing and quality control that have been done by the trusted of the home country, while more labor intensive and less value added tasks are outsourced such as purchase of raw materials and mass production of the products done in cheaper developing host countries (Escalona \& Ramoz, 2014). Therefore, the hypothesis was not supported, and the Country of Origin does not influence Purchase Intention positively.

Based on the results of the second hypothesis test stating that Perceived Quality has positive and significant effect on the Purchase Intention of Etude Cosmetics. It can be seen by the results of the hypothesis testing, that the results of data were positive and significant. This relates to the previous researches that stated perceived quality as one of the most important aspects of a product's consumer purchase intention (Nor et al., 2016), as well as previous researchers' theory stating that perceived quality of a product has a positive and significant impact on purchase intention (Degoma \& Shetemam, 2014). This result is also consistent with the results of research conducted by Ko et al. (2015) stating that perceived quality influence can reflect the customer's overall feeling about a product and can have a positive and significant impact on purchase intention. Therefore, Hypothesis 2 is supported.

Based on the results of the third hypothesis test stating that Brand Image affects positively and significantly on the Purchase Intention of Etude Cosmetics, it can be seen by the results of the hypothesis testing that the results of data were positive and significant. This relates to the previous researches stating that Brand image is proven to have positively significant and direct effect on a consumer's purchase intention (Chih et al., 2013). Therefore, Hypothesis 3 is supported.

\section{Implications}

Based on the conclusions, the implications are stated as follows; First, As the perceived quality 
and brand image affect significantly and positively on the purchase intention of Etude House cosmetics, the company should focus on increasing the perceived quality of the products and build positive brand images with aesthetically pleasing and trendy product packaging in order to create better consumer purchase intentions. Based on the descriptive analysis, The Perceived Quality has the most significant influence on the purchase intention, but from the indicator PQ6 with the description "The brand Etude House makes me look classy" has the lowest mean value compared to the other indicators. This means that compared to the other indicators, how the brand image of Etude makes them look class, it is not as great as the other indicators. Therefore, Etude House cosmetics should focus on producing products with better quality, which could make the consumers look more sophisticated and classy. Second, Etude House should increase their attempt to strengthen and improve the brand awareness of the Etude House logo, which will increase the ability for the consumers to be able to distinguish the brand from other competitor brands, and produce aesthetically pleasing packaging, and the associate the brand with K-beauty even more.

\section{Limitations and Future Research}

Based on the results of this study, there are some limitations experienced when carrying out this research which are as follows; First, the study was only conducted on students of UPH, so that the scope of this study is limited and it only produces research on consumer purchase intention in a narrow environment. It is recommended that future research should be conducted to examine a larger variety of population and wider scope, the common population of Indonesia, in other regions of Indonesia, and other Universities, both State and Private Universities in Indonesia. Second, PLS-SEM has its disadvantages, namely that it cannot test the feasibility of the model. Therefore, it is expected that the next researcher can analyze using the CB (Covariance Based) -SEM (Structured Equation Modeling) approach which has the advantage of being able to test the feasibility of the model. Lastly, Convenience Sampling has a disadvantage that can result in sampling error. Therefore, the next researcher is advised to use a purposive sampling approach that requires researchers to specifically target the more knowledgeable and experienced samples for better and more detailed results.

\section{References}

Abdillah, W., \& Hartono, J. (2015). Partial Least Square (PLS): alternatif Structural Equation Modelling (SEM) dalam penelitian bisnis (pp. 112-270). Yogyakarta: CV Andi Offset.

Adhitya, A. (2018). Beauty Product Opportunities to Indonesia, Malaysia and Vietnam. Retrieved from https://www.austrade.gov.au/ArticleDocuments/1418/2018_webinar_presentation_Beauty_Pr oduct_Opportunities_Indonesia_Malaysia_Vietnam.pdf.aspx.

Batra, R., \&Homer, P. M. (2004), The Situational Impact of Brand Image Beliefs. Journal of Consumer Psychology, 14(3), 318-330. https://doi.org/10.1207/s15327663jcp1403_12

Beneke, J., Flynn, R., Greig, T., \& Mukaiwa, M. (2013). The influence of perceived product quality, relative price and risk on customer value and willingness to buy: a study of private label merchandise. Journal of Product \& Brand Management, 22(3), 218-228. 
https://doi.org/10.1108/JPBM-02-2013-0262

Bhakar, S. S., Bhakar, S., \& Bhakar, S. (2013). Relationship between country of origin, brand image and customer purchase intentions. Far East Journal of Psychology \& Business, 10(2), $132-160$.

Chih, C, Y., Lin, P. J., \& Chen, C. S. (2013). How brand image, country of origin, and self, congruity influence internet users, purchase intention. society for research. Society for Research, 41(4), 599-612. https://doi.org/10.2224/sbp.2013.41.4.599

Consumer goods to Indonesia - Austrade. (2018). Retrieved from https://www.austrade.gov.au/australian/export/exportmarkets/countries/indonesia/industries/c onsumer-goods.

Czinkota, M. R., \& Ronkainen, I. A. (2010). International marketing. OH: South-Western Cengage Learning.

Degoma, A., \& Shetemam, E. (2014). The effect of country of origin image on purchase intention: A case study on Bahir Dar University instructors. J Account Mark, 3(109), 1-5. https://doi.org/10.4172/2168-9601.1000109

Erdogmus, I., \& Turan, I. B. (2012). The role personality congruence, perceived quality and prestige on ready-to-wear brand loyalty. Journal of Fashion Marketing and Management, 16(4), 399-417. https://doi.org/10.1108/13612021211265818

Escalona, O. A., \& Ramos, P. D. (2014). Global production chains in the fast fashion sector, transports and logistics: the case of the Spanish retailer Inditex (pp. 113-127). Investigaciones Geográficas, Boletín, núm. 85, Instituto de Geografía, UNAM, México.

Ghozali, M., \& Supriyanti. (2014). Pengaruh kualitas pelayanan dan harga terhadap kepuasan pelanggan expedisi di Surabaya. Jurnal ilmu \& Riset Manajemen, 3(3), 117-231.

Gillespie, K., McBride, J. B., \& Riddle, L. (2010). Globalization, biculturalism and cosmopolitanism: The acculturation status of Mexicans in upper management. International Journal of Cross Cultural Management, 10(1), 37-53. https://doi.org/10.1177/1470595809359581

Hair, J. F., Hult, G. T. M., Ringle, C. M., \& Sarsted, M. (2014). A primer on partial least squares structural equation modeling (PLS-SEM). Los Angeles: SAGE Publications, Inc.

Hair, J. F., Money, A. H., \& Samouel, P. (2014). Research methods for business. Southern Gate: John Wiley \& Sons Ltd.

Hanzaee, K. H., \& Khosrozadeh, S. (2011). The effect of the country-of-origin image, product knowledge and product involvement on information search and purchase intention. Middle-East Journal of Scientific, 8(3), 627.

Hartono, B. (2013). Sistem informasi manajemen berbasis komputer. Jakarta: Rineka Cipta.

Jaafar, S. N., \& Laip, P. E. (2012). Consumers' perception, attitudes and purchase intention 
toward private label product in Malaysia. Asian Journal of Business and Management Sciences, 2(8), 73-90.

Keller, K. L. (2012). Impact of brand related attributes on purchase intention of customers (pp. 117-181). A study about the customers of Punjab, Pakistan.

Ko, E., Kyung, H. K., \& Hao, Z. (2015). A cross cultural study of antecedents of purchase intention for sports shoes in Korea and China, Routledge Informa Ltd Registered in England., Mortimer Street, London, UK. Journal of Global Academy of Marketing Science, 18(1), 157-177, https://doi.org/10.1080/12297119.2008.9707281

Kotler, P., Armstrong, G., Saunders, J., \& Wong, V. (2008). Principles of marketing. Corporate Communications: An International Journal, 11(3), 95-176.

Kotler, P., \& Keller, K. L. (2009). Marketing management (13th ed., pp. 65-378). New Jersey, Pearson Education Ltd.

Kotler, P., \& Keller, K. L. (2012), Marketing management. Pearson Education Inc. Upper Saddle River, 14(2), 121-378.

Mowen, J. C. (2006). Consumer behaviour. New Jersey: Prentice-Hall.

Nazir, M. (2005). Metode Penelitian. Bogor: Ghalla Indonesia., 200-207.

Nor S. N., Yunus, M., \& Edura, E. R. (2016). Procedia economics and finance. Faculty of Business Management, Universiti teknologi MARA. Elsevier B.V. https://doi.org/10.1016/S2212-5671(16)30135-6

Parkvithee, N., \& Miranda, M. J. (2012). The interaction effect of country-of-origin, brand equity and purchase involvement on consumer purchase intentions of clothing labels. Asia Pacific Journal of Marketing and Logistics, 24(1), 7-22. https://doi.org/10.1108/13555851211192678

Priyanga, D. R., \& Krishnaveni, P. (2016). Perception of women consumer towards branded cosmetics in Nagapattinam district. International Journal of Science and Research, 5(7), $652-654$.

Rezvani, S., Dehkordi, G. J., Rahman, M. S., Fouladivandal, F., Eghtebasi, S., \& Habibi, M. (2012). A conceptual study on the country of origin effect on consumer purchase intention. Asian Social Science, 8(12), 205-215. https://doi.org/10.5539/ass.v8n12p205

Rosyidi, S. (2009). Analisis pengaruh brand, country of design dan country of assembly pada persepsi kualitas dan niat beli. Potensio, 11(1), 10-33.

Schiffman, L. G., \& Kanuk, L. L. (2009). Consumer Behavior (pp. 325-356). New Jersey: Prentice Hall.

Shah, S. S. H., Aziz, J., Jaffari, A. R., Waris, S., Ejaz, W., Fatima, M., \& Sherazi, S. K. (2012). The impact of brands on consumer purchase Intentions, Iqra University, Islamabad Campus, Pakistan. Asian Journal of Business Management, 4(2), 105-110. 
Shamindra, N. S., \& Saroj, K., (2011). The effect of country of origin on brand equity: an empirical study on generic drugs. Journal of Product \& Brand Management, 20(2), 130-140, https://doi.org/10.1108/10610421111121125

Smith, S. (2013). Determining Sample Size. Retrieved from https://www.ndsu.edu/gdc/wp-content/pdf/Determining-Sample-Size.pdf

Sugiyono. (2008). Metode penelitian kuantitatif kualitatif dan $R \& D$ (pp. 36-154). Bandung: Alfabeta.

Sugiyono. (2013). Metode penelitian pendidikan pendekatan kuantitatif, kualitatif, dan R\&D (pp. 170-264). Bandung: Alfabeta.

Tulipa, D., \& Muljani, N. (2015). The country of origin and brand image effect on purchase intention of smartphone in Surabaya - Indonesia. Mediterranean Journal of Social Sciences, 6(5), 64-70. https://doi.org/10.5901/mjss.2015.v6n5s5p64

Wang, C. L., Li, D., Barnes, B. R., \& Ahn, J. (2012). Country image, product image and consumer purchase intention: Evidence from an emerging economy. International Business Review, 21(6), 1041-1051. https://doi.org/10.1016/j.ibusrev.2011.11.010

Wijanto, S. (2008). Structural Equation Modeling dengan Lisrel 8.8. Graha Ilmu, Yogyakarta.

Wijaya, B. S. (2013). Dimensions of Brand Image: A conceptual review from the perspective of brand communication. European Journal of Business and Management, 5(31), 55-65.

Wu, P. C. S., Yeh, G. Y., \& Hsiao, C. R. (2011). The effect of store image and service quality on brand image and purchase intention for private label brands. Australasian Marketing Journal, 19(1), 30-39. https://doi.org/10.1016/j.ausmj.2010.11.001

Wulandari, D. (2013). Hingga 2018, Etude House Tambah 40 Gerai Baru. Retrieved from https://mix.co.id/headline/hingga-2018-etude-house-tambah-40-gerai-baru/.

Yasin, N. M., Noor, M. N., \& Mohamad, O. (2007). Does image of country of origin matter to brand equity? Journal of Product and Brand Management, 16(1), 38-40. https://doi.org/10.1108/10610420710731142

Yee, C. J., \& San, N. C (2011). Consumers' perceived quality, perceived value and perceived risk towards purchase decision on automobile. American Journal of Economics and Business Administration, 3(1), 47-57. https://doi.org/10.3844/ajebasp.2011.47.57

30 Negara Asal Impor Terbesar Untuk Produk Hasil Industri. (2018). Retrieved from http://kemenperin.go.id/statistik/negara.php

\section{Copyrights}

Copyright for this article is retained by the author(s), with first publication rights granted to the journal.

This is an open-access article distributed under the terms and conditions of the Creative Commons Attribution license (http://creativecommons.org/licenses/by/4.0/). 